\title{
Problem of Mountain Agriculture in Azerbaijan Solutions
}

\author{
RAE Z H Aliyev* \\ Institute of Erosion and Irrigation NAS of Azerbaijan, Baku
}

Submission: January 04, 2018; Published: January 11, 2017

*Corresponding author: RAE Z H Aliyev, Institute of Erosion and Irrigation NAS of Azerbaijan, Az1007 Baku, Azerbaijan, Email: zakirakademik@mail.ru

\begin{abstract}
The article in the main task is to use low-intensity irrigation under conditions of acute shortage of water resources in mountain and foothill areas of the republic. Therefore, it is necessary to correct existing deficiencies in the plant water supply, through the development of a series of activities that allow better use of irrigated lands at the expense of low-intensity water supply according to the crop needs during their growing season, eliminating erosion and soil erosion, which creates conditions for environmentally friendly products and etc.
\end{abstract}

Keywords : Intensity; Vegetation; Sustainable; Productivity; Erosion; Salinization; Waterlogging; Ground water

\section{Review}

For the rapid development of agricultural production in Azerbaijan is a new irrigation technology, which provides for daily water consumption of the plants in their growing season. In wetlands is not enough, especially in the mountains, irrigation is one of the decisive factors in the cultivation of high and stable yields with / agricultural crops, regardless of weather conditions [1-4]. The factors directly affecting the hobby crop yields and increase productivity per hectare of arable land and / agricultural land at the lowest cost of labor and resources, include: the use of mechanization, automation, expansion of the area sown crops and varieties of intensive type. Irrigation increases the efficiency of intensification factors, application of chemicals, complex mechanization, strain renovation, intensive technology. It allows you to create a large area of guaranteed production of grain, feed, and increase productivity, technical, vegetable and other crops.

For all this, we study methods of proper regulation of water consumption and power plants with the help of irrigation and fertilizer consumption and the accumulation of soil nutrients, protect it from water and wind erosion, Stalinization and water logging. In addition, irrigation greatly changes the conditions of plant nutrition. Nitrates, being exposed to the active zone of the root system activity, improve nutrition of plants [3-8]. Irrigated soils in Azerbaijan cover 1450 thousand Hectare. Of these, 757.2 thousand Hectare or $51.8 \%$ are saline soils. An area slightly saline soil is 387.1 thousand hectares. Srednezasolennyh 185.5 thousand hectares, strongly and very strongly saline 115.1 thousand Hectare including the area of 357.3 thousand Hectare of irrigated soils are common slabosolen-tsevanye, 43,2 thousand Hectare silnosolentsevatye environment and soil.
Saline soils, on which grow from / crops, common in areas in Salyanah Mugan, Shirvan plain. Saline soils cover a large area, strongly saline common in south-eastern Shirvan. From suitable agricultural land irrigated 593.0 thousand Hectare of drained. Of these, 310.4 thousand Hectare is open, 269.4 thousand Hectare of indoor and 132.0 thousand Hectare of drainage. However, it should be noted that the system is in operation, a long period of repairs and reconstruction have been neglected due to which the system is out of order. As a result, every year the environmental and reclamation condition deteriorated soil, ground water rises, part of the irrigated land is saline, coming out of agricultural use. Danger of salinity is high groundwater salinity. It should be noted that the groundwater at a depth of less than one meter is 68.7 thousand hectares, from 1.0 to 2.0 meters cover an area of 486.1 thousand hectares.

In connection with the transgression of the Caspian Sea and rising groundwater levels, 475 of 1,45 mln. Hectares of irrigated land, where you can get $85-90 \%$ of agricultural products were subjected to Stalinization in varying degrees [5]. Currently, this process progress pensates on the area 103 thousand. Hectares of the ground water level has risen to the surface of the soil, in the area of 167 thousand Hectare is in the process of salinity and rising groundwater. In recent years, during the construction reclamation-irrigation facilities, in some cases, the wrong geological, hydro geological, reclamation approach is its negative impact on the environment. It should be noted that in the farms, Placing in the central and eastern parts of the Ter-Ter region in farms and residential areas of the western part of the Barda, Shamkir, Gazakh, Agstafa, Alazan-Agrichayskoy valley, in the village Tun-Tun Gabelinskogo district, also in Sharur district 


\section{Global Journal of Otolaryngology}

of the Nakhichevan Autonomous Republic of the irrigated farms flooded as a result of raising the groundwater.

Despite the fact that the Kura-Araz lowland was designed drainage network with a projected depth of 2.5-3.5 m, studies have shown in recent years, $75-80 \%$ of groundwater fell by 1.0 $1.5 \mathrm{~m}$, and during the growing season of plants to $0-1.0 \mathrm{~m}$, which shows their steady state. This process affects the secondary Stalinization of irrigated lands. It should also be noted that the level of groundwater is, it increased in the irrigation period. The reason for this conclude-sists in the fact that leaking irrigation period (loss) of water from the network of channels and accessing the subsurface volume and increases the level of groundwater. In areas with a strong salinity in the composition of the groundwater contains various salts, so salinity developing intensively $[2,6]$. As groundwater salinity on the land area of 489.6 thousand Hectare of 1.0-3.0 g / 1, 449.3 thousand Hectare of more than $3.0 \mathrm{~g} / \mathrm{l}$. Overall assessment of irrigated land depends on the state of groundwater and the degree of soil salinity:
a) 396.1 thousand hectares -.. «Good»
b) 663.7 thousand hectares -. «Satisfactory»
c) 385.1 thousand hectares -. «Not satisfactory»

It should be noted that most of the usable agricultural land is located in a flat part of the country. This is part of different hot climate, minor rainfall (200-300 mm / year), although volatility is $800-1000 \mathrm{~mm}$. To obtain high crop yields of agricultural crops in the area necessary to carry out irrigation and reclamation activities.

Surface water resources of 32.2 billion mantas. m3. Per year and in dry years it is reduced to 23.2 billion mantas. m3. Of these volumes of water at a fraction of its own water resources accounts for 10 mlr.m3. Or $30 \%$ of the water resources of the republic, the remaining $70 \%$ are formed EA expense of neighboring republics. The artificial water storage basins in the country are 21.5 billion mantas. m3. A significant portion of this amount is used in hydropower and irrigation. In general, the republic annually uses $11-12$ mlr.m 3 water, from which $67 \%$ is used in agriculture, $20-25 \%$ in industry, and the rest goes to the drinking water intake. It should be noted that in the Republic of 3200 hectares of irrigated area of 1.45 million hectares are irrigated by the same resources. The specified area provided engineering and irrigation and drainage network.

It should also be noted that in 1970-1990 years in the country were established distribution system, drainage network, pumping stations large water management, consisting of water basins. In the years to 875 thousand Hectare of irrigated area, new irrigation systems were built $[2,4]$. As a result of such measures the length of irrigation canals reached 73 thousand. Km. However, the result is not the correct operation and maintenance of this system is partially collapsed and out of order, which has a negative impact on the growing crops. It should be noted that out of 8641.5 thousand hectares area, 4514.5 thousand hectares are agricultural land, makes it possible to produce $85 \%$ of this production. Consequently, due to the complexity of physical and gegraficheskih conditions and anthropogenic impacts, $42.3 \%$ of the land subjected to varying degrees of erosion processes. In addition, as noted above, the soil in the area of the Kura-Araz lowland strongly saline.

The total amount of saline land in the country is around $2 \%$, or 600 thousand Hectare, although some of them are equipped with a drainage network. For their washing and recovery requires additional fresh water. In Azerbaijan, in addition to the plain terms, has crossed slope conditions, which requires a special approach solving problems of water supply selhozproizduction in the developing regions of mountain agriculture with the use of low-intensity irrigation systems. Low-intensity irrigation unlike traditional irrigation characterized in that when using this technique maintained the humidity in the active layer at an optimal level of moisture exchange (NV 85-90\%) without significant variations between the upper $(100 \% \mathrm{NV})$ and the bottom $(60-70 \% \mathrm{NV})$ outside. Leaking at the same time in the soil processes are not stressful, destroying its structure and character are held in comfortable conditions for the formation of fertility on water and aeration.

Today's main task is to use low-intensity irrigation under conditions of acute shortage of water resources in mountain and foothill areas of the republic. Therefore, it is necessary to correct existing deficiencies in the plant water supply, through the development of a series of activities that allow better use of irrigated lands at the expense of low-intensity water supply according to the crop needs during their growing season, eliminating erosion and soil erosion, which creates conditions for environmentally friendly products and etc. Difficult geographical location of natural resources leads to a reduction in fertile land and ecological imbalance. To solve these problems in the first place requires the expansion of cultivated areas and increase crop yields.

It should be noted that the water supply to the region of the Greater Caucasus is divided into south and north-eastern slope of the Greater Caucasus Mountain Range and Gobustan. Please note that in high Hone southern slope of the average annual flow module is $45 \mathrm{l} / \mathrm{s} \mathrm{km} 2$ or $1,500 \mathrm{~mm}$. Photo module is reduced to $150 \mathrm{~mm}$ with decreasing altitude when exiting rivers in AlazanAvtoranskuyu valley. Climate and geographic location affect the change in flow. On the southern slope at an altitude of 800 $900 \mathrm{~m}$ there is an intense fascination with the drain here the annual rainfall exceeds $800 \mathrm{~mm}$. And with a decrease in rainfall runoff slows down the growth. In the north-eastern part of the Greater Caucasus stock is uniform. [4,8]. Here passion flow occurs between the side and the Main Caucasus Range in the zone includes the upper part of the river Kdialchay, Kusarchay, Karachai and Velvelechay. It should be noted here that the value of annual runoff vary between $300-600 \mathrm{~mm}$, where the annual flow of the rivers flowing down from the sides of the ridge is different from the group of the Main Caucasian ridge rivers. 
That is, the increase in runoff increases and at an altitude of $1000-2000 \mathrm{~m}$ varies from 200 to $600 \mathrm{~mm}$. This is due to the large amount of precipitation. The area from the side of the ridge to the Caspian Sea to Atachai River, the upper reaches of rivers Pirsagat Sumgait and to the entrance of Gobustan are relative to water supply district, where the average annual flow module is from 1 to $5 \mathrm{l} / \mathrm{s} \mathrm{km} 2$. The rivers of this region do not provide water for the national economy. Here the lack of water is compensated by Samur- Absheron channel that throws runoff. Samur, Kudialchay and Velvelechay in this area. Gobustan and Absheron considered the least water availability. Here, the average annual flow is less than $1 \mathrm{l} / \mathrm{s} \mathrm{km} 2$, and in the coastal zone of the Caspian Sea is reduced to zero. Therefore, this region is not agriculturally used. Annual runoff of the rivers of the Greater Caucasus is $5.52 \mathrm{~km} 3$ or $175 \mathrm{~m} 3 / \mathrm{s}$.

And this is the average annual runoff module the whole territory of $2.93 \mathrm{l} / \mathrm{s} \mathrm{km} 2$ or $92 \mathrm{~mm}$, ie $15.3 \%$ of the water resources of the local rivers of Azerbaijan. Along with this arrangement in the Lesser Caucasus mountain ranges complicates the distribution of runoff. In the Lesser Caucasus on water availability and distribution of runoff are 4 areas:

a) The north-eastern slope;

b) The northeastern slope of the south-eastern part;

c) in the Nakhichevan Autonomous Republic of southwestern slope of the Zangezur range;

d) southeastern slope of the south-eastern part of the Lesser Caucasus and Karabakh Plateau.

It should be noted that the first two points comprising the right-bank tributaries of the river. Chickens with the adjacent areas, and the second left-bank tributaries punkta- 2 p. Araxa with areas. It should also be noted that the Lesser Caucasus is different from the Greater Caucasus that is at an altitude of 3000 $\mathrm{m}$ and more water availability reaches $900 \mathrm{~mm}$ or $25-28 \mathrm{l} / \mathrm{s} \mathrm{km} 2$. Here, the river network is distributed throughout the territory of the Lesser Caucasus is very uneven. In its development affects physical and geographical factors.

The density of the river network varies in different altitudinal zones. The greatest of its development reaches the river network in the mountains at an altitude of 1000-2500 m in the middle mountain zone. Above and below the hydrographic network underdevelopment. Investigations revealed that the most dense river network are different right-bank tributaries of the Kura River, the river basin. Shahdag ridge to the river. $[4,6,8]$ Shamhorchay where its density ranges from 0.75 to 1.0 $\mathrm{km} / \mathrm{km} 2$. A Right-bank tributary of the Kura River is located in the north-eastern part of the Lesser Caucasus and Nagorno Karabakh. It should be noted that such a position different hydrographic and related agricultural condi- tions affect the agricultural production. For the development and practical use of sown areas in the mountainous regions of the country is extremely necessary to conduct a series of ameliorative measures, taking into account the natural - economic conditions of each region. It should be noted that in the regions, especially agriculture inflicts great damage to water erosion, developed in the mountainous areas of the country.

The main methods of erosion control - this agronomic, agrochemical, Forest melioration, hydraulic reclamation, lowintensity irrigation and other activities carried out in the republic. Particular importance is attached to the steepness of the slopes and the degree of soil erosion. On silnosmytyh rotations soils it is advisable to saturate the legumes. On steep slopes used for gardens, buffer strips, ie, narrow strips of perennial grasses or shrubs, a strip across the slope. In hydraulic engineering reclamation following irrigation methods are used: surface, sprinkler, subsurface drip, aerosol and other forms of low-intensity irrigation $[2,3,7]$. As a result of numerous studies proved that the slopes 4-80 can be used irrigation carried out with the machine such as DTT feed Orosi tive water by a flexible hose is wound sprinkling machines, stationary and semipermanent systems of irrigation self-oscillating pulse action and Cidade with automatic control, etc.. wherein the sector angle is calculated depending on the angle of the irrigation area $[1,4]$.

Among the activities contributing to the development of land for agricultural purposes also includes the improvement of irrigation in a mountain area. These improvement methods include:

a) Layout of slopes;

b) Selection of the optimal direction irrigation furrows;

c) Watering through the packed aisle on the wheels of the tractor furrows;

d) Selection of the optimum length of the furrow irrigation and spray costs;

e) The device perfect farm irrigation systems and technical means of distribution of water in the furrow, ensure precise dosing and regulation of irrigation jet in time;

The introduction of low-intensity irrigation systems with automated process control. Planning and correctly chosen direction irrigation furrows are mandatory techniques in the development of sloping lands, the amount of which depends on the power melkozemistogo soil. Along with the above for irrigation on steep slopes it is necessary to introduce a perfect on-farm irrigation system, which should provide a clear controlling the flow of irrigation water. In this best meets these requirements tubular irrigation system consisting of a closed distribution piping and irrigation pipes with holes. It is recommended that the application for vineyards over an area of 100 hectares of closed irrigation system (drip irrigation, drippulse, etc.) [3] And cotton with an area of over 3,000 hectares and for irrigation of row crops (pulse irrigation, aerosol, pulsed irrigation self-oscillating action synchronously-pulsed irrigation, etc.) Semi samonapornaya irrigation network passed industrial test on large slopes $(0,008-0,3)$ areas. 
Closed irrigation system allows you to quickly and given the technology to supply water to any area of irrigated land. It should be noted that in the evaluation and selection of irrigation methods should, use the indicators that define the requirements of agricultural production to the irrigation technique based on agro-biological, soil-reclamation, organizational, economic and business conditions [4,5]. When traditional methods of irrigation on the slopes of the majority of cases observed surface runoff and linear erosions, reduces soil fertility. The goal of eliminating irrigation erosion is offered the possibility of using when watering with a fairly low intensity of water supply, allow for continuous irrigation according to water consumption with / agricultural crops with the help of which found a wide field of implementation of LED design, Sida and others. Developed by the author at the Institute of «Erosion and Irrigation» Ministry of Agriculture of AR., characterized by very low average intensity of rain (0,001-005 $\mathrm{mm} / \mathrm{min}$.), it is acceptable for irrigation in mountain and foothill regions.

\section{References}

1. Aliev B H, Aliev Z H, Aliev I N (2017) Technology and technology of lowintensity irrigation in the mountainous region of Azerbaijan. // Elm Publishing House Bkau. 1999220 p.

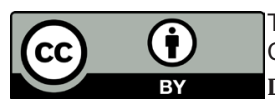

This work is licensed under Creative Commons Attribution 4.0 License DOI: $10.19080 /$ GJO.2018.13.555851
2. Aliev ZH, Aliev BH (2017) Technology and technology of low-intensity irrigation in the mountainous region of Azerbaijan. Elm Publishing House, Baku, 1999-220 sec.

3. Aliev BH, Aliev IN, Agayev NA (2002) Ecological safe technology of micro-irrigation of agricultural crops in conditions of insufficiently moistened zones of Azerbaijan. Ziya-Nurlan Publishing House Baku, $163 \mathrm{~s}$.

4. Aliev BH (2001) Zoning of the territory of the Republic of Azerbaijan for the choice of progressive irrigation technology. Monograph, ZiaNurlan Publishing House. Baku, 249.

5. Aliev Z H, Aliev B H (1997) Investigations of complex indicators of reliability of micro-irrigation systems for conditions of mountainirrigated agriculture in Azerbaijan. NTO NGO Impulse Baku, 59.

6. Aliev Z H, Aliev B H (1999) Prerequisites for solving the problems of water availability of agricultural production in the mountainous and foothill regions of Azerbaijan. Proceedings of the Research Institute “Erosion and Irrigation” Baku. 125-129.

7. Babayev A Kh (2012) Monitoring of soil quality and environmental monitoring. Baku. 255 pp.

8. Mamedov G Sh, Khalilov M Yu (2005) Ecology and environmental protection. Baku. 880.

Your next submission with Juniper Publishers will reach you the below assets

- Quality Editorial service

- Swift Peer Review

- Reprints availability

- E-prints Service

- Manuscript Podcast for convenient understanding

- Global attainment for your research

- Manuscript accessibility in different formats

( Pdf, E-pub, Full Text, Audio)

- Unceasing customer service

Track the below URL for one-step submission https://juniperpublishers.com/online-submission.php 